\title{
Piotr Grzymisławski Zwrot performatywny w teatrze postdramatycznym
}

\begin{abstract}
Grzymisławski Piotr, Zwrot performatywny w teatrze postdramatycznym [Performative turn in postdramatic theatre]. "Przestrzenie Teorii" 17. Poznań 2012, Adam Mickiewicz University Press, pp. 51-61. ISBN 978-83-232-2449-5. ISSN 1644-6763.

In this article I try to identify changes that occur in the communication process in the theatre, which I call acceptance process. The core of perception in dramatic theatre up to now was the denial (term proposed by Anne Ubersfeld), which allows to participate in theatrical work. In theatre which leaves dramatic form, so-called postdramatic theatre, there is an acceptance process. This new situation in the theatre, by turning towards enforcing performative functions in the communication theatre, leads to changes in the relationship between stage and audience, their mutual temporary and spatial arrangement. In the contemporary art, not only in theatre, Auditorium turns into an Autorium - watching works becomes literally a creative activity, within which there are as many performances as many persons participating in an event - or as many images in each of performative entity's mind.
\end{abstract}

Teatr jest jednym z tych elementów rzeczywistości, które nie tylko stanowią o jej charakterze, ale przede wszystkim oddają specyfikę zachodzących zmian w społeczeństwie, są ich odzwierciedleniem. Parafrazując słowa Guya Deborda, w spektaklu mamy do czynienia z wizją świata, która stała się rzeczywista, znalazła swój materialny wyraz¹. Zdarzenie teatralne staje się zatem „światopoglądem”. Dlaczego tak się dzieje? Decyduje o tym istota teatru - tworzywa przewidującego dla nadawcy i odbiorcy wspólny czas i przestrzeń, w której emisja i recepcja zachodzą równocześnie. Zachowania na scenie i na widowni tworzą wspólny tekst. Dzięki materialności komunikacji teatr staje się metatekstem społeczeństwa.

Niezwykle dynamiczne zmiany, jakie zachodzą w naszej kulturze, takie jak rozwój technologii informatycznej, zjawisko globalizacji, nieodwracalnie wpływają na nasz sposób bycia w świecie i percepcję, powodując $\mathrm{w}$ efekcie zmiany $\mathrm{w}$ sposobie komunikacji społecznej. Są to zmiany poważne, obok których nie sposób przejść obojętnie. Różnice, jakie się ujawniają w naszych czasach, znajdują odzwierciedlenie w teatrze. Pojawiają się one na płaszczyźnie leksykalnej i praktycznej. Świadomość artystyczna społeczeństwa poddanego upraszczającej technologii diame-

${ }^{1}$ G. Debord, Społeczeństwo spektaklu, przeł. M. Kwaterko, Warszawa 2006, s. 34.

2 Tamże. 
tralnie zmienia stosunek do dominującego jak do tej pory w kulturze imperatywu literackiego. Jeszcze dalej idąca rewolucja zachodzi w obrębie formy. Postmodernizm skłonny jest do autorefleksji i autotematyzmu. Wektor sztuki skierowany jest do środka, działalność artystyczna sama dla siebie staje się tematem i punktem odniesienia. Podobnie dzieje się w teatrze, który znajduje się dziś pomiędzy dawnym porządkiem i tym, co przyniósł mu postmodernizm. Charakterystycznym dla Europy i wciąż będącym w powszechnej świadomości jedynym istniejącym modelem teatru jest teatr dramatyczny, głęboko zanurzony w paradygmacie kultury literackiej. Żywi się takimi pojęciami, jak narracja, figuracja, fabuła, całość, iluzja czy reprezentacja. W dobie rozwoju masowych mediów elementy te przestają funkcjonować $\mathrm{w}$ teatrze. Podstawowa zasada przedstawiania na scenie mowy i gestów poprzez naśladowczą grę dramatyczną, przy zachowaniu niepisanej umowy między sceną a widownią o autentyczności i autonomiczności prezentowanego świata, wydaje się anachronizmem i sprawia, że teatr w swojej dramatycznej formie przestaje być wiarygodny. Trudno sobie wyobrazić tworzywo teatralne bez wyżej wymienionych fundamentalnych elementów przynależnych do teatru dramatycznego, ale równocześnie niemożliwe stało się zachowanie tej dawnej formy. Teatr został „obnażony”, w następstwie czego sam musiał się sobie przyjrzeć i odkryć własną fasadowość. Dawne narzędzia komunikacji teatralnej przestały pełnić najważniejsze funkcje, nie stanowią już zasady regulującej, choć należy podkreślić, że teatr z nich nie zrezygnował. Zmieniło się natomiast, powtarzając za Hansem-Thiesem Lehmannem $^{3}$, rozłożenie akcentów, które kładzie się na poziomy przedstawienia teatralnego. Tekst lingwistyczny i tekst przedstawienia zostały zepchnięte na dalszy plan względem „tekstu performance'u”.

W studiach performatywnych zwraca się uwagę na rodzaj napięcia, jakie wytwarza się między sceną a widownią. Wynika to $\mathrm{z}$ tego, że w teatrze coraz silniej widoczna staje się sytuacja, w której uprzywilejowany zostaje tekst performance'u. Powodem są wszechobecne w życiu codziennym media, które systematycznie wypierają teatr jako prymarne medium reprezentacyjne. Teatr zmienia swój charakter i skupia się na materialności komunikacji, która stanowi o jego niepowtarzalności i jednocześnie staje się jego zasadniczym wyróżnikiem.

Zdarzenie, do jakiego dochodzi podczas trwania widowiska teatralnego, spotkanie się ludzi, wchodzących we wspólny świat znakowania, wykreowany przez działanie artystyczne i jednocześnie odrębny od rzeczywistości, z której tu przybyli, jest, w tym nowym porządku estetycznym,

3 Por. H.-T. Lehmann, Teatr postdramatyczny, przeł. D. Sajewska, M. Sugiera, Kraków 2004, s. 131. 
wyeksponowane szczególnie. Performatywny charakter widowiska oznacza nie tylko podkreślenie zdarzeniowości teatru. Zmiana estetyki teatralnej jest zaledwie wynikiem przeformułowanej pozycji sztuki teatralnej. Zwrócenie ku performatywności widowiska oznacza przede wszystkim wzmożone oddziaływanie na widza środkami artystycznymi, wykraczającymi poza klasyczne schematy. A więc wytrącenie go z biernej postawy obserwującego, skłonienie do podjęcia działania w obrębie tworzonego w czasie rzeczywistym spektaklu. Działanie to jest tylko pozornie niczym nieskrępowane. Realizacja widowiska odbywa się bowiem we wcześniej zaplanowanych przez artystę ramach. Jednak wykonanie artystycznych założeń pozostaje w gestii nie tylko autora, ale również odbiorcy. Aktywne współautorstwo widzów tworzy intersubiektywny twór artystyczny, w którym subiektywność autora dopuszczona jest do głosu w podobnym stopniu, w jakim dopuszczane są głosy pozostałych podmiotów przestrzeni widowiska.

Obrazy performatywne, jakie generowane są w nowej rzeczywistości teatralnej, mają siłę tworzenia nowych stanów rzeczy. Podobnie jak obraz reklamowy kreuje potrzebę posiadania lub obraz pornograficzny wywołuje podniecenie. Doświadczenie uczestników przed spektaklem jest różne od doświadczenia tuż po nim. Zostaje wzbogacone o to, co stało się ich udziałem $\mathrm{w}$ trakcie trwania widowiska. Można powiedzieć, że nie ma w tym nic nowego. Od zawsze teatr dostarczał mniej lub bardziej silnych wrażeń, które pozostawały w pamięci widzów na długo po skończeniu spektaklu. Mimo to sytuacja ta nie jest taka sama. Czym innym są doznania związane $\mathrm{z}$ obserwacją tego, co przedstawiane, a rzeczywiste doświadczenie uczestnictwa w realności scenicznej.

Anne Ubersfeld, definiując katharsis (pojęcie od zawsze przynależne teatrowi), charakteryzuje równocześnie jedną z najbardziej podstawowych cech komunikacji teatralnej:

Na tym polega katharsis: tak, jak marzenie senne spełnia w pewien sposób pragnienia osoby śpiącej, tworząc fantazmaty, podobnie tworzenie konkretnej rzeczywistości, jednocześnie poddanej sądowi negującemu jej przynależność do świata rzeczywistego, uwalnia widza, który patrzy na to, jak jego lęki i pragnienia realizują się lub są zażegnywane, przy czym on sam nie jest ich ofiarą, choć bierze w tym pewien udział ${ }^{4}$.

W teatrze dramatycznym, przedstawiającym akcję i mającym fabułę wynikająca z dramaturgicznej partytury, dominantą komunikacji jest negacja. Pojęcie to określa stosunek odbiorcy do komunikatu teatralnego, który traktuje jako nieprawdziwy. Rekwizyty, elementy scenografii, w końcu aktorzy grający na scenie, są rzeczywiści, ale podlegają teatrali-

${ }^{4}$ A. Ubersfeld, Czytanie teatru I, przeł. J. Żurowska, Warszawa 2002, s. 36. 
zacji i w efekcie uzyskują dla widza status nierzeczywisty. Według Ubersfeld teatr podobny jest do marzenia sennego, „to konstrukcja wyobraźni, o której widz wie, że jest zdecydowanie oddzielona od sfery egzystencji codziennej”. Świadomość tego, że jest się postawionym wobec fikcji, wywołuje poczucie bezpieczeństwa niezbędne dla przeżywania w teatrze dramatycznym. Odbiorca, wiedząc, że jego prywatna przestrzeń pozostaje niezagrożona, jest $\mathrm{w}$ stanie identyfikować się z dramatycznymi antagonistami, przeżywać ich perypetie i doznawać związanych z nimi uniesień. Kryje się w pojęciu negacji aspekt wychowawczy i poznawczy. Przeżywanie nie swoich losów, uczestniczenie w fantazmacie, odpowiada prostemu schematowi uczenia się na cudzych błędach bądź też przeżywania stanów, których nie można doświadczać na co dzień. Aby miało to znaczenie, musi dojść do wstrząsu, silnego doznania wywołanego scenicznym obrazem. Oczywiście nie chodzi tu o siłę, która mogłaby stanowić zagrożenie dla zdrowia psychicznego widza. Przeżywanie niejako w zastępstwie jest możliwe dzięki identyfikacji w procesie odbiorczym i towarzyszącemu jej jednocześnie dystansowi, który wynika z refleksji, jaka musi nieprzerwanie towarzyszyć widzowi w trakcie spektaklu.

W ramach modelu teatralnego zawsze istnieją równocześnie i bezwzględnie dwa kosmosy: sceny i widowni. Obydwa są rzeczywiste. Sceniczna rzeczywistość, w obrębie której znajdują się przedmioty i postaci, ma niepodważalny status bytowy. Jednak przez zapośredniczenie ramy scenicznej przestrzeni, niezależnie od tego, jaki model przestrzenny będzie realizowany w dziele teatralnym, elementy składające się na rzeczywistość teatralną zawsze będą poddawane teatralizacji, prowadząc do wyodrębnienia jej od rzeczywistości przynależnej publiczności. W tych dwóch przestrzeniach obowiązują odrębne prawa. Zasiadać przy stole, który znajduje się na scenie, mogą jedynie postaci sceniczne. Dla widza przedmiot ten będzie tylko ikonicznym znakiem stołu w rzeczywistości pozascenicznej. Będzie odsyłał do znanego każdemu odbiorcy pojęcia stołu, ale pozostanie tylko referentem, ponieważ żaden $\mathrm{z}$ obserwatorów na widowni nie może przy nim zasiąść. Podobnie jest $\mathrm{z}$ działaniem na scenie i jego konsekwencjami. Morderstwo dokonane na postaci nie jest istotnym morderstwem, gdyż dotyczy postaci, a nie aktora przynależącego do ich rzeczywistości. Publiczność może, w procesie identyfikacji, przeżywać emocje, jakie targają postaciami dramatycznymi, ale będą to emocje zapośredniczone scenicznym obrazem. Strach postaci dramatycznej nie zostaje przetransponowany na rzeczywistość poza sceną, ponieważ nie zmusza widzów do podjęcia działania obronnego, czy mającego czemuś przeciwdziałać. Widzowie poddają mu się, fetyszyzują wyobrażenie stanu

\footnotetext{
5 Tamże.
} 
lękowego, a jego ślady odnajdują we własnym doświadczeniu i przeżywają go, pozostając jednocześnie w bezpiecznej strefie. Skoro przeżycia towarzyszące akcji scenicznej są jedynie projekcją „prawdziwego” doznania, nie mają właściwości performatywnych. Nie mają trwałych konsekwencji i przede wszystkim nie zmieniają nic w przestrzeni publiczności, której członkowie pozostają po spektaklu w niezmienionych względem siebie relacjach.

Opisany schemat znakowania i wiążąca się z nim funkcja negacji odpowiadają powszechnym wyobrażeniom o dziele teatralnym i uważane są za konstytutywne dla wszystkich możliwych jego rodzajów. Podstawą stanowiaca o teatralnym świecie jest nienaruszalność miejsca scenicznego, która nie została złamana, co podkreśla Ubersfeld, pomimo jej zrewolucjonizowania $\mathrm{w}$ wieku XX doprowadzającego do zniesienia „granicy między publicznością i akcją sceniczną, widzami i aktorami, nie narusza podstawowego rozróżnienia: nawet gdyby aktor siedział na kolanach widza, niewidoczna rampa, jak prąd o napięciu stu tysięcy woltów, będzie ich dzieliła jeszcze gruntowniej"6. Jest w tym twierdzeniu wiele racji. Trudno jednak nie zauważyć, że referencyjny model teatru, a nawet jego autoreferencyjność, pojawiająca się w czasach awangardy i wzmagająca się jeszcze w postmodernizmie, nie obejmuje coraz silniej zarysowującej się przemianie w stronę performatywności komunikatu we współczesnym teatrze. Mowa już była o tym, że przeżywanie związane z obserwowaną akcja $\mathrm{w}$ teatrze dramatycznie organizowanym nie jest tym samym doświadczeniem, które staje się udziałem widza podczas jego uczestnictwa w realności scenicznej teatru niedramatycznego. Skoro fundamentem dla sposobu percepcji w teatrze dramatycznym był do tej pory proces negowania, pozwalający na uczestnictwo $\mathrm{w}$ dziele teatralnym, to $\mathrm{w}$ teatrze odchodzącym od dramatyczności, nazywanym teatrem postdramatycznym, można mówić o procesie akceptacji. Nowa sytuacja w teatrze, poprzez zwrot $\mathrm{w}$ stronę wzmocnienia funkcji performatywnej $\mathrm{w}$ komunikacie teatralnym, doprowadza do zmian $\mathrm{w}$ relacji między sceną a widownią, ich wzajemnego czasowego i przestrzennego usytuowania. Modyfikuje się też funkcja teatralnego zdarzenia w przestrzeni społecznej. Dochodzi bowiem do ujednolicenia obydwu rzeczywistości i stworzenia wspólnej realności dla sceny i widowni. Aby to osiągnąć, potrzebne jest stworzenie wspólnego prawa rządzącego tymi przestrzeniami i przede wszystkim obowiązującego jednakowo dla wykonawców - performerów i odbiorców - uczestników widowiska. Wiąże się to z poważnymi zmianami w systemie organizacji znakowania, które mają prowadzić do stworzenia sytuacji niewymuszającej na widzu rozpoznania działania

\footnotetext{
${ }^{6}$ Tamże.
} 
artystycznego jako nierzeczywistego. Jest to możliwe dzięki zmianie statusu tekstu dramatycznego $\mathrm{w}$ dziele teatralnym, który był do tej pory jego najistotniejszym elementem, odsyłającym do przedstawianej, dzięki temu niezależnej od widzów, rzeczywistości. Tekst lingwistyczny i wiążący się z nim tekst przedstawienia zostaje zepchnięty na plan dalszy. Należy zauważyć, że proces ujednolicenia nie przybliża teatru do rzeczywistości pozascenicznej, ale prowadzi do zaanektowania dla siebie realności obydwu przestrzeni - sceny i widowni - tworząc wspólna rzeczywistość, która jednakże wciąż pozostaje zapośredniczona artystycznie. Wielu krytyków i ludzi teatru widzi w „zwrocie performatywnym” zagrożenie dla teatru, jako że ujawnia się tutaj zaniechanie podstaw charakterystycznych dla dotychczasowego modelu przedstawiania związanego $\mathrm{z}$ teatralizacją. Jednak paradoksalnie przestrzeń działań wciąż podlega teatralizacji, z tym zastrzeżeniem jednak, że staje się ona totalna, doprowadzając do teatralizacji widzów, którym pozostawiona jest możliwość wyboru stopnia, w jakim chcą się poddawać temu procesowi. Uzyskują oni dzięki temu pozycję współtwórcy, performera, który wykonuje widowisko. Tylko pozornie tak rozumiany udział odbiorcy w dziele nasuwa tezę o śmierci autora, którą w latach siedemdziesiątych ogłosił Roland Barthes ${ }^{7}$. We współudziale widza $\mathrm{w}$ performatywnym widowisku teatralnym ujawnia się charakterystyczna dla „zwrotu performatywnego" również w innych dziedzinach sztuki myśl rehabilitująca instytucję autora. Ewa Domańska pisze o tym zjawisku następująco:

Powiedziałabym zatem, że konstruktywizm, poststrukturalizm i narratywizm ze swoimi hasłami śmierci podmiotu, śmierci autora, antyesencjalizmem, „afirmacją słabego podmiotu", który jest konstytuowany przez dyskurs, system, czy relacje wiedzy - władzy itd. odebrały podmiotowi sprawczość, które współczesne awangardowe kierunki w humanistyce usiłują odzyskać. Zatem „zwrot performatywny” może być także widziany w kategoriach „powrotu silnego podmiotu”, choć rzecz jasna, nie chodzi tutaj o podmiot humanistyczny, esencjalny, homogeniczny. Ten nowy, silny podmiot $\mathrm{z}$ założenia jest hybrydą (uwaga na możliwość kolejnej esencjalizacji i fetyszyzacji pojęcia). Następuje zatem przekwalifikowanie aspektów, które przedtem identyfikowane były z mocnym podmiotem. Mocny podmiot performatywny to taki podmiot, który tworzy się w happeningach, wydarzeniach, których nie jest widzem, ale inicjatorem i sprawcą. Podmiot ten nie jest też „podmiotem samotnym” (podmiot romantyczny), lecz współdziała zawsze z innymi podmiotami i „aktorami” (z bytami ludzkimi i nie-ludzkimi) ${ }^{8}$.

${ }^{7}$ Śmierć autora - esej teoretycznoliteracki Rolanda Barthes'a, opublikowany w 1968 roku, a zarazem postulat nawołujący do nieodczytywania tekstu literackiego przez pryzmat tzw. intencji autorskiej. W Polsce artykuł ukazał się po raz pierwszy w czasopiśmie „Teksty Drugie” w 1999 roku, autorem przekładu jest Michał Paweł Markowski.

8 E. Domańska, „Zwrot performatywny” we wspótczesnej humanistyce, „Teksty Drugie" 2007, nr 5, s. 56. 
Kategoria uczestnictwa jako akt tworzenia w niedramatycznych performance'ach i happeningach narzuca się samoistnie. Dochodzi w nich do radykalnego przełamania rozdziału między widzem a performerem. Jednak nowe modele partycypacji w zdarzeniu teatralnym przybierają różne formy, które nie zawsze są łatwe do określenia, pomimo że dochodzi w nich do wartościowania podmiotów sprawczych tworzących się poprzez działanie. Sposoby uczestnictwa w obrębie performatywnej formy teatralnej częściej przebiegają znacznie mniej spektakularnie. We współczesnej sztuce, nie tylko teatralnej, audytorium zamienia się w autorium - oglądanie dzieła staje się dosłownie twórczym zajęciem, w obrębie którego istnieje tyle spektakli, ile osób uczestniczących w zdarzeniu - ile obrazów w głowie każdego podmiotu performatywnego. W nowej rzeczywistości teatralnej jest wiele form wzmagających reakcję. Działanie nie musi przybierać formy akcji, która wpłynie na bieg scenicznych zdarzeń. Może do niego dojść w indywidualnym wymiarze poszczególnych uczestników. Taką formą może być działanie intelektualne, wzbudzone przez wpływanie na obserwatora bodźcami, skłaniającymi jego organizm do reakcji na oglądane obrazy. Psychosomatyczna reakcja stymuluje intelektualny odbiór. Ciało podmiotów sprawczych, zarówno widzów, jak i artystów, podlega tym samym bodźcom, a więc podlega tej samej aktywności. Nie ma już możliwości zapośredniczonego przeżywania, jakie towarzyszą odbiorowi w teatrze dramatycznym i tym samym nie sposób egzorcyzmować tego doświadczenia. Współczesna kompozycja sceniczna nigdy nie jest kompletna, nie tworzy całości gotowej do interpretacji i z góry założonego sposobu przeżycia. Realizacja jest dopełniana przez zindywidualizowany odbiór i dopiero w trakcie trwania widowiska tworzy obraz realizowanego (już nie przedstawianego) świata.

Ekspozycja materialnego charakteru komunikatu w teatrze stanowi wyraz posthumanistycznej kondycji w badaniach kulturowych. „Zwrot performatywny" możemy w kontekście teatru określać, transponując kategorię teatru postdramatycznego jako zwrot postdramatyczny. Traktuje on o sprawczości nie tylko ekofaktów (bytów naturalnych), ale również o sprawczości artefaktów (rzeczy należących do materii nieożywionej). Skłania się zatem w stronę performatywnej funkcji wszelkich bytów znajdujących się w obrębie spektaklu. Dla rozjaśnienia istoty rozpatrywanego zagadnienia w kontekście teatru postdramatycznego, można by zaryzykować stwierdzenie, że teatr dramatyczny, który opierał się na istocie dramatyczności, przynależał $\mathrm{w}$ zasadzie jedynie do idiomu przedstawieniowego - a więc tworzył zwarty obraz, wedle estetyki powierzchni stanowiącej stałą, gotową i całościową przestrzeń - i w rezultacie prezentował obraz, który został dany w rzeczywistości, uzyskując charakter przedmiotowy, ale równocześnie w akcie przedstawieniowym podlegał upodmiotowieniu przez ludzkie, sprawcze działanie. 
Materialność komunikacji teatralnej w performatywnych formach polega na obecności „tu i teraz” podmiotów sprawczych, którymi są wszystkie elementy substancjalne znajdujące się $\mathrm{w}$ zbiorze stworzonej przestrzeni teatralnej, obejmującej artystów, publiczność i wszelkie byty nieludzkie ${ }^{9}$. Jest to możliwe dzięki ujednoliceniu rzeczywistości wszystkich podmiotów performatywnych, funkcjonujących w czasoprzestrzeni widowiska w ramach jednej realności, rządzonej przez te same prawa.

$\mathrm{W}$ tak rozumianej realności czasoprzestrzennej widowiska znaleźć można powód, dla którego współczesna sztuka, również teatralna, nosi wyraźne znamiona autoreferencyjności. Nie przedstawia bowiem, jak w przypadku modelu teatru dramatycznego, innej rzeczywistości, ale tworzy rzeczywistość wspólną dla przestrzeni widowiska i tym samym odnosi się jedynie do samej siebie. Nie przedstawia dla kogoś, lecz sama dla siebie jest przedstawianiem. Zanika wyraźna opozycja pomiędzy nadawcą a odbiorcą. Widz już nie tylko dekoduje znaczenia, które są przesyłane w procesie komunikacji teatralnej. Przeciwnie, zważywszy na to, że zostaje on zaanektowany do wspólnej rzeczywistości z performera$\mathrm{mi}$, pełni również funkcję podmiotu znakotwórczego $\mathrm{w}$ przestrzeni działania artystycznego. Mamy zatem do czynienia z nowym modelem komunikatu teatralnego opartego na zasadzie wzajemności.

Mówiąc o zmianach charakterystyki komunikatu teatralnego i rodzących się z nich relacji pomiędzy podmiotami sprawczymi spektaklu, trzeba podkreślić, że nie chodzi tu o specyfikę teatru w teatrze. Metateatralny charakter teatru barokowego czy elżbietańskiego i jeszcze wielu innych, w których pojawia się odniesienie do przedstawieniowej natury tworzywa teatralnego, wciąż mieści się wyłącznie w ramach idiomu przedstawieniowego. Jest spiętrzonym wariantem reprezentacji obejmującej świat przedstawiony, mieszczący się w ramach jeszcze innego świata przedstawianego.

Eksponowanie materialności komunikacji jest wynikiem przemian, jakie zaszły w sztuce wizualnej pod wpływem nauki - a konkretnie fizyki

${ }^{9}$ Lehmann, pisząc o nurcie teatru postantropocentrycznego, składającego się na postdramatyczny teatr, opisuje rodzaje widowisk, które nie tylko eksponują sprawczość artefaktów scenicznych, ale posługują się nimi jako jedynymi elementami sprawczymi widowiska: „Mogłyby się w nim znaleźć teatry przedmiotów, które obywają się zupełnie bez żywych wykonawców, teatr techniki i maszyn (Survival Research Laboratories) i ponadto takie teatry, które ludzkie kształty integrują jako element podobnych do krajobrazów struktur przestrzennych. To estetyczne figuracje, które utopijnie wskazują na alternatywę dla antropocentrycznego ideału podporządkowania natury. Kiedy ludzkie ciało, postawione na równi z przedmiotami, zwierzętami i liniami energii utworzy z nimi jedną rzeczywistość (jak dzieje się w przypadku cyrku - stąd czerpana z jego oglądania głęboka przyjemność), to powstanie teatr jako dzieło innej rzeczywistości niż ta przedstawiana przez podporządkowującego sobie naturę człowieka”. H.-T. Lehmann, Teatr postdramatyczny, s. 125. 
- na początku XX wieku. Teoria względności Einsteina i zasada nieoznaczoności Heisenberga sprawiły, że świat utracił raz na zawsze swoją substancjalną stabilność. Pojęcie materii zostało wzbogacone o energię. Od tej pory zmieniło się pojmowanie dzieła sztuki, które zyskało charakter dynamiczny. Stało się nie tylko przedmiotem materialnym, ale przede wszystkim uporządkowanym przez działanie artysty tworem o charakterze energetycznym. W sztuce, również teatralnej, pojawił się „układ odniesienia" jako istotny element kreowania przestrzeni artystycznej. $\mathrm{W}$ teatrze przedawangardowym mieliśmy do czynienia $\mathrm{z}$ przestrzenią statyczną w swej trójwymiarowości, tworzącą zaledwie iluzję głębi. Dopiero pojawienie się kategorii czasu jako czwartego wymiaru ukazało przestrzenne rzeczy w ruchu i zmienności. Gra świateł, podkreślająca następujące po sobie w czasie wydarzenia, czy ruch aktorów na scenie, nieodbywający się już na nieruchomym, zgeometryzowanym tle, ale wchodzący $\mathrm{w}$ interakcję $\mathrm{z}$ dynamiczną dwuwymiarową przestrzenią, były poważnymi zmianami w sposobie teatralnej prezentacji świata, na które znaczny wpływ miała świadomość czasu wielkich przemian w fizyce, o fundamentalnych dla sztuki wartościach, takich jak czas i przestrzeń. Pojęcie continuum czasoprzestrzennego w sztuce przyczyniło się do obalenia twierdzenia Lessinga o rozróżnieniu na sztuki czasowe i przestrzenne.

Energia $\mathrm{w}$ tak ujmowanej formie teatralnej pojawia się $\mathrm{w}$ procesie wzajemnych relacji podmiotów, jakie zachodzą w trakcie spektaklu. Mowa więc tu o swoistej estetyce relacyjności w obrębie dzieła. W tym kontekście materialność komunikatu teatralnego nie odnosi się sensu stricto do podkreślenia pojęcia materialności teatralnych elementów, ale do procesualnego charakteru dzieła, konstytuowania się artystycznej materii w jej ciągłym ruchu, zależnym od obecności widzów. Pojmowanie teatru jako sztuki odbywające się „tu i teraz” jest podkreślane we współczesnej myśli krytycznej. Imperatyw czasu teraźniejszego w przestrzeni teatralnej określa podmioty teatralne - o czym była już mowa wcześniej w kontekście ich sprawczości. Kategoria performatywności jest podstawowym i najistotniejszym założeniem charakteryzującym przestrzeń. Można zatem mówić o niej jako o przestrzeni działania, co pociąga za sobą istotne zmiany w jej charakterystyce. Tym, co o niej stanowi, nie będzie już zamknięta $\mathrm{w}$ architektonicznej bryle przestrzeń, która musi przewidywać oddzielne miejsce dla wykonawców i odbiorców. Organizację elementów w obrębie „sprawiania się” performatywnego spektaklu będzie narzucać działanie. Czasoprzestrzenne usytuowanie podmiotów (również widzów) zależeć będzie od ich aktywności. Przestrzeń tworzy się zatem w wyniku temporalnie zróżnicowanych relacji pomiędzy nimi. Podmioty dane przez twórcę - aktorzy/performerzy, przedmioty czy zwierzęta - 
mają w sobie imperatyw sprawczy, niejako z mocy swojej definicji. Widz również zostaje uczestnikiem działań, choć tego imperatywu nie posiada. Tylko od niego zależy, w jakim stopniu chce się angażować i wchodzić $\mathrm{w}$ relacje kontekstualne - $\mathrm{z}$ jednej strony obejmujące dzieło, z drugiej zaś jego otoczenie. Jakkolwiek zakres działań widza zależy tylko od niego, to $\mathrm{w}$ ramach formy performatywnej, przynajmniej w minimalnym stopniu, jest on obserwatorem i uczestnikiem, ponieważ jego subiektywne widzenie ma konsekwencje dla całego kontekstu przestrzeni, w której dokonuje się akt percepcji. Sposób percepcji nie jest wyłącznie sprawą jego wewnętrznego przeżycia, lecz integralną częścią całego pola relacji. Współuczestnicy sytuacji artystycznej wchodzą we wzajemne relacje podmiotu percypującego przedmiot na zasadzie sprzężenia zwrotnego. Była już mowa o upodmiotowieniu wszelkich sprawczych elementów spektaklu, wchodzących, w rezultacie działania, we wzajemne relacje interakcji i transakcji o charakterze wielokierunkowym i wielowymiarowym, będąc jednocześnie w każdym momencie trwania widowiska podmiotem i przedmiotem procesów percepcyjnych. Jako element pola relacji widz współkształtuje sytuację teatralną i jego kontekst w takiej samej mierze, w jakiej jest współkształtowany.

Opisana estetyka relacyjności, właściwa dla wszelkich nurtów teatru postdramatycznego, czyni kategorię sprawczości konstytutywną dla nowej rzeczywistości teatralnej. Pojęcie sprawczości implikuje uczestnictwo wszystkich podmiotów w performowanej rzeczywistości artystycznej. Wymiar, w jakim widz uczestniczy w spektaklu teatru postdramatycznego, zależy tylko od niego, nie decyduje on jednak o formie tej partycypacji, która odpowiednia jest dla określonego typu widowiska. Formy te są bardzo zróżnicowane i obejmują znacznie więcej rodzajów niż tylko uczestniczenie poprzez włączenie się do działania w dosłownym rozumieniu, angażowanie się $\mathrm{w}$ akcję $\mathrm{i}$ wchodzenie $\mathrm{w}$ relację kontaktu fizycznego $\mathrm{z}$ innymi podmiotami, jak może się dziać chociażby w happeningu. Często forma uczestnictwa przebiega znacznie mniej spektakularnie. Przykładem może być tu sytuacja widza wobec postmodernistycznego spektaklu tanecznego. Relacje, jakie zachodzą pomiędzy nim a tancerzem, mają charakter performatywny, bez potrzeby celowego działania podejmowanego przez obserwatora. Tym, co łączy wszystkie te formy uczestnictwa, jest nowy sposób posługiwania się znakami i oddziaływania bodźcami wchodzącymi inaczej niż do tej pory $\mathrm{w}$ relację $\mathrm{z}$ ciałem odbiorcy. Teatr postdramatyczny zastępuje akcję dramatyczną nowym rodzajem akcji, która angażuje widza nie tylko emocjonalnie, ale przede wszystkim fizycznie.

Ubersfeld dostrzega w pojęciu oksymoronu podstawę teatru. Wszystkie jego elementy: czas, przestrzeń, postać sceniczna, aktor czy figura 
tekstu noszą znamiona sprzeczności ${ }^{10}$. Kategoria przeżywania $\mathrm{w}$ teatrze dramatycznym kryje w sobie antynomię, jako że jest figurą rzeczywistego doświadczenia.

Doświadczenie teatralne jest modelem zredukowanym. Wskutek tego pozwala oszczędzić nam prawdziwego doświadczenia, egzorcyzmuje to doświadczenie, daje nam przeżyć per procura wzruszenia i czyny, które życie codzienne potępia, jak morderstwo, kazirodztwo, gwałtowna śmierć, zdrada małżeńska, bluźnierstwo, wszystko, co jest zakazane, istnieje obecne na scenie. Ból i śmierć są bólem i śmiercią na odległość; banalna prawda: znajdujemy się w komfortowej sferze katharsis. Nierozwiązywalnemu konfliktowi przynosi ona rozwiązanie idealne i wychodzimy zadowoleni - to się ułoży bez nas ${ }^{11}$.

Tworzenie obrazów w teatrze ma egzorcyzmować doznania, zaklinać je tak, żeby nie miały one więcej dostępu do odbiorcy w jego codziennym życiu. Można zatem traktować teatr jako swoisty trening emocjonalny, mający przygotować do „prawdziwego" życia. Jednak nasuwa się pytanie, czy w obecnej sytuacji, gdy człowiek, który - rozumując za Baudrillardem - jest podmiotem fraktalnym ${ }^{12}$, będzie w stanie podjąć tę teatralną grę reprezentacji i iluzji? Jeżeli założyć, że struktura medialnie zapośredniczonej percepcji powstała na skutek poddawania człowieka permanentnie powtarzanym obrazom, to $\mathrm{w}$ efekcie staje się ona znacznie bardziej powierzchowna i odporna na bodźce klasycznego modelu teatru. Aby teatr mógł dotrzeć ze swoim komunikatem do współczesnego odbiorcy, musi posługiwać się doraźnymi bodźcami. Możliwe to jest dzięki wspomnianej estetyce akceptacji, która zakłada wspólną rzeczywistość i tym samym wyklucza figurę teatralnego doświadczenia. Teatr postdramatyczny przyjmuje strategię afirmacji doświadczenia, tworząc wspólną przestrzeń znakowania i oddziaływania, a zatem tworzy formę postredukowaną, ponieważ - będąc efektem artystycznej działalności i kreacji redukującej intensywność doznania do czasu trwania spektaklu i przestrzeni jego działania - równocześnie sprawia, że nie jest ona zapośredniczeniem doświadczenia, w równym stopniu dotyczy bowiem widza i performera.

10 Por. A. Ubersfeld, Czytanie teatru I, s. 227.

11 Tamże, s. 228.

12 „Zwielokrotniony przez własne wizerunki człowiek, wierny własnemu modelowi, staje się podmiotem fraktalnym. Rozproszony w tym, co identyczne, w widmie identyczności, zmierza do utożsamienia się ze swymi cząsteczkami (Dziś już żadna dramaturgia ciała, żaden występ nie odbywa się bez monitorów kontrolnych - nie dlatego wszak, byśmy się w nich mogli przeglądać lub dzięki dystansowi i magii lustra odbijać, lecz raczej w tym celu, byśmy dostapili natychmiastowej, powierzchownej refrakcji. [...] Refrakcja, która nie ma w sobie już nic z obrazu, sceny czy siły reprezentacji, która w ogóle nie służy grze ani wyobrażeniu, lecz zawsze służyć będzie - określonej grupie, działaniu, jakiemuś wydarzeniu lub przyjemności - podłączeniu (connected) do siebie samego". J. Baudrillard, Świat wideo i podmiot fraktalny, [w:] Po kinie? Audiowizualność w epoce przekaźników elektronicznych, red. A. Gwóźdź, Kraków 1994, s. 251. 
